\title{
The Dabie Extensional Tectonic System: Structural Framework
}

\author{
Quanlin Hou, ${ }^{1}$ Hongyuan Zhang, ${ }^{2}$ Qing Liu, ${ }^{1}$ Jun $\mathrm{Li}^{3}{ }^{3}$ and Yudong $\mathrm{Wu}^{4}$ \\ ${ }^{1}$ Graduate University of the Chinese Academy of Sciences, Beijing 100049, China \\ ${ }^{2}$ School of Earth Sciences and Resources, China University of Geosciences, Beijing 100083, China \\ ${ }^{3}$ Institute of Geology and Geophysics, The Chinese Academy of Sciences, Beijing 100029, China \\ ${ }^{4}$ MLR Key Laboratory of Metallogeny and Mineral Assessment, Institute of Mineral Resources, CAGS, Beijing 100037, China
}

Correspondence should be addressed to Quanlin Hou, quhou@gucas.ac.cn

Received 10 May 2012; Revised 31 July 2012; Accepted 22 August 2012

Academic Editor: Yi-Wen Ju

Copyright ( 2012 Quanlin Hou et al. This is an open access article distributed under the Creative Commons Attribution License, which permits unrestricted use, distribution, and reproduction in any medium, provided the original work is properly cited.

A previous study of the Dabie area has been supposed that a strong extensional event happened between the Yangtze and North China blocks. The entire extensional system is divided into the Northern Dabie metamorphic complex belt and the south extensional tectonic System according to geological and geochemical characteristics in our study. The Xiaotian-Mozitan shear zone in the north boundary of the north system is a thrust detachment, showing upper block sliding to the NNE, with a displacement of more than $56 \mathrm{~km}$. However, in the south system, the shearing direction along the Shuihou-Wuhe and Taihu-Mamiao shear zones is tending towards SSE, whereas that along the Susong-Qingshuihe shear zone tending towards SW, with a displacement of about $12 \mathrm{~km}$. Flinn index results of both the north and south extensional systems indicate that there is a shear mechanism transition from pure to simple, implying that the extensional event in the south tectonic system could be related to a magma intrusion in the Northern Dabie metamorphic complex belt. Two ${ }^{40} \mathrm{Ar}-{ }^{39} \mathrm{Ar}$ ages of mylonite rocks in the above mentioned shear zones yielded, separately, $\sim 190 \mathrm{Ma}$ and $\sim 124 \mathrm{Ma}$, referring to a cooling age of ultrahigh-pressure rocks and an extensional era later.

\section{Introduction}

Dabie area is well known of owning one largest area of ultrahigh-pressure metamorphic belt (UHPB) in the world, located, as a tectonic zone, between the North China Block and Yangtze Block (Figure 1).

The Dabie area experienced a complicated tectonic evolution during the Mesozoic and resulted in thrust-nappe, extensional detachment, and strike-slip structures $[1,2]$. Much attention has been paid to the tectonic evolution of the Dabie Mountains, with most tectonic models proposing although compressional tectonism for the formation of the orogen. However, Mesozoic extensional structures in the Dabie Mountains are also obvious and important for understanding the Mesozoic tectonic regime inversion from compression to extension occurred throughout the Dabie Mountains and even in the eastern North China Block [3].

The purpose of this paper is to figure out the structural framework of the Dabie Late Mesozoic extensional detachment system by analyzing deformation, tectonic styles, and physical conditions, to constrain the time of the extensional tectonics, and finally to discuss the tectonic implications.

\section{Tectonic Background}

The general geology of the Dabie area has been described in multiple publications [5-13]. Briefly, from north to south, the Dabie Mountains can be divided into four major tectonic units: (1) the North Huaiyang Flysch belt (NHMB) mainly composed of the Foziling Group $\left(\mathrm{Pt}_{2}\right)$; (2) the Northern Dabie metamorphic complex belt (NDMCB), composed dominantly of granitic gneisses of TTG composition, with the Xiaotian-Mozitan and the Shuihou-Wuhe shear zones defining the northern and southern boundaries, respectively; (3) the ultrahigh-pressure metamorphic belt (UHPB) refers to the Central Dabie ultrahigh pressure metamorphic complex and is bounded in the south by the Taihu-Mamiao shear zone; (4) the high-pressure belt (HPB) refers to the Southern Dabie high-pressure blueschist/greenschist terrane [10], 


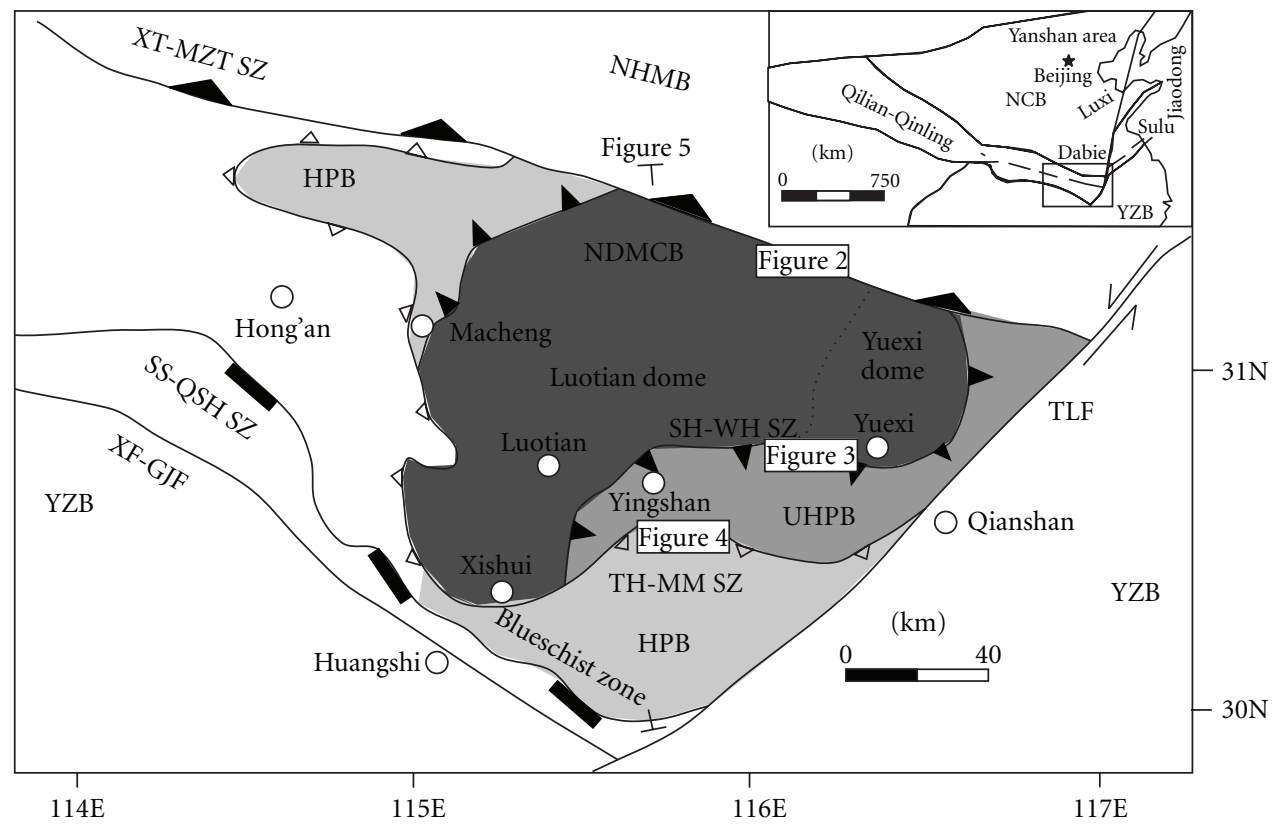

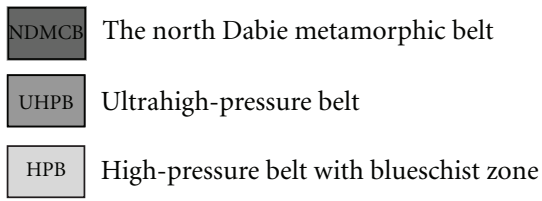

FIgURE 1: Simplified map of late Mesozoic main shear zones in eastern Dabie Mountain, Central China (after Suo et al., 2000 [4]). NCC: Northern China Block; YZC: Yangzi Block; NHMB: North Huaiyang metamorphic belt; NDMCD: North Dabie metamorphic complex belt; UHPB: Ultrahigh-pressure metamorphic belt; HPB: high-pressure metamorphic belt; SH-WH SZ: Shuihou-Wuhe shear zone; TH-MM SZ: Taihu-Mamiao shear zone; SS-QSH SZ: Susong-Qingshuihe shear zone; XT-MZT SZ: Xiaotian-Mozitan shear zone; TLF: Tancheng-Lujiang Fault (Tanlu Fault); XF-GJF: Xiangfan-Guangji Fault.

whose southern margin is defined by the Susong-Qingshuihe shear zone (Figure 1).

Several contrasting tectonic models have been proposed for the Dabie orogenic belt. Suo et al. $[4,14]$ identified extensional tectonism in the Dabie orogen during the middlelate Mesozoic. Song [15] defined extensional structures in metamorphic rocks with different ages that formed prior to the continental collision that produced the Qinling-Dabie orogen. Based on geochemical analyses of the Wangmuguan pluton in Xinxian, Zhang et al. [16] proposed that the pluton formed within extensional conditions after the formation of the orogen and was related to lithosphere detachment. A twostage extension model proposed by Jin et al. [17] describes extension during the early Caledonian period, which resulted in the local sea and the beginnings of the Dabie-Qinling metamorphic core complex; extension during the Yanshan period coincided with the formation of the core complex and the intrusion of granite. Wang and Yang [18] investigated the extensional domes in the Dabie Mountains. Li [19] studied the late Mesozoic extension in the eastern part of the Dabie Mountains. Among these studies, there is a hot debate about the timing of the onset of extension, its direction, and tectonic styles. In this paper, we describe the results of our field observations and geochemical analysis, which provide some new insights into understanding the evolution of the late Mesozoic extensional detachment zones in the Dabie area.

\section{Deformation History of Extensional Detachment Zones}

The NDMCB is the crystalline core of the late Mesozoic extensional structures. These features can be divided into two tectonic systems, the north extensional tectonic system and the south extensional tectonic system (Figure 1).

3.1. The North Extensional Tectonic System. The principal detachment shear zone is the XT-MZT SZ, which is located between the NHMB and the NDMCB. To the east (i.e., along the Huoshan-Zhujiapu Road), the brittle-ductile extensional shear zone dips to the $\mathrm{NE}\left(60^{\circ}\right)$ at an angle of $30^{\circ}-40^{\circ}$ to the horizontal. To the west (i.e., in the Jinzhai-Qingshan area), the shear zone dips towards the NNE-NE $\left(30^{\circ}-50^{\circ}\right)$. From south to the north, the dip angle changes from steep (about $70^{\circ}$ ) to gentle. Hence, it is shaped like a shovel and is locally sinuate (orientation $220^{\circ}$ and dip $20^{\circ}$ ). The displacement orientation on the shear zone is to the NE or NNE. Noticeably, the extensional shear zone locally in the 

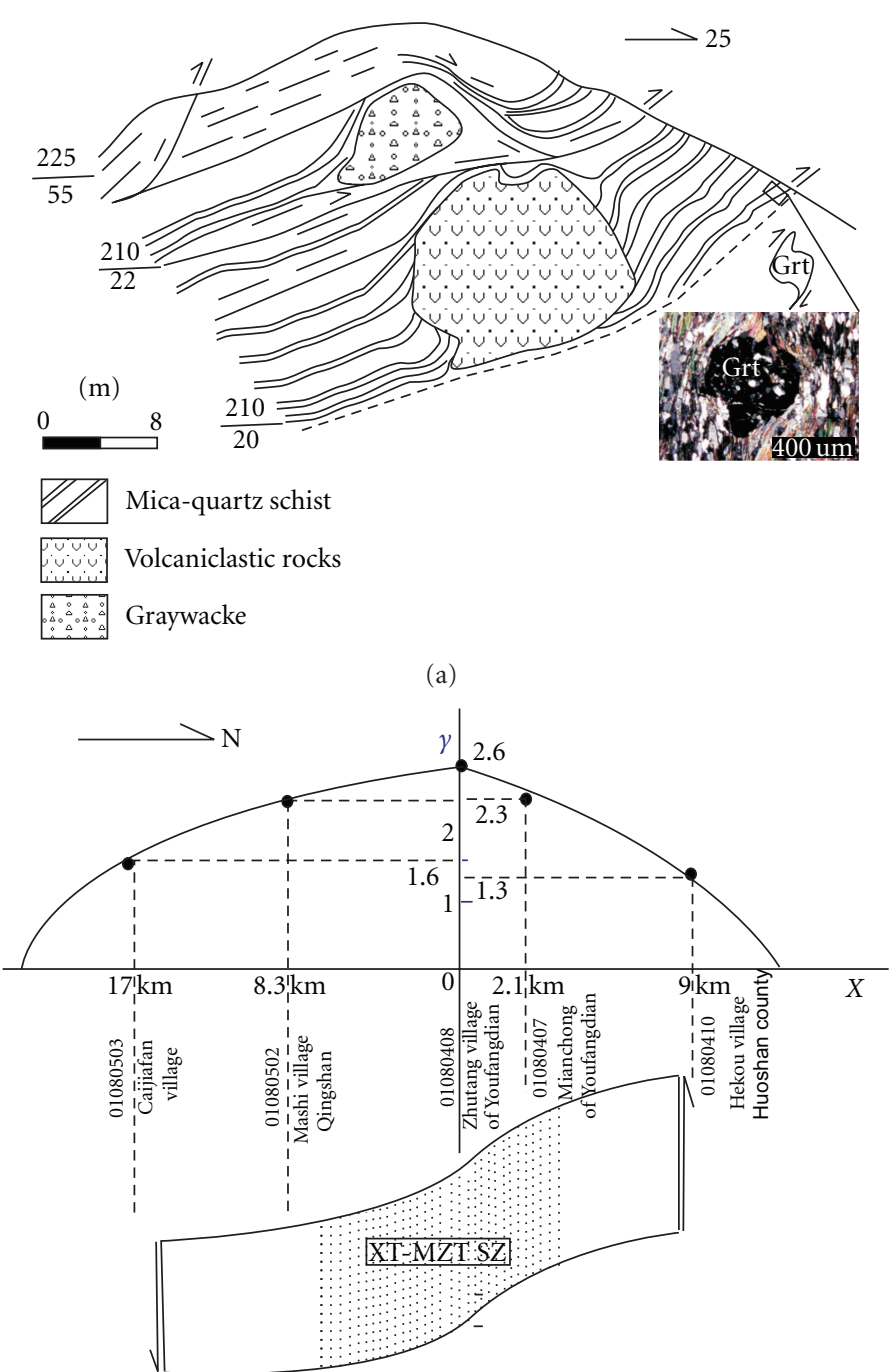

(b)

FIgure 2: (a) The north extensional detachment zone suggests extension shearing after late Jurassic from the XT-MZT SZ. Late Jurassic volcaniclastic tectonite blocks are hosted by mica-quartz schist $\left(\mathrm{Pt}_{2}\right)$. The photo right below shows snow ball structure observed by microscopy. (b) The shear length of the XT-MZT SZ is more than $56 \mathrm{~km}$.

NHMB has developed into an inconsecutive extensional crenulation cleavage $\left(\mathrm{C}^{\prime}\right.$, the same as $\mathrm{S}_{3}$ in some places) with NE-dip. The extensional crenulation cleavage is an important character of the north extensional tectonic system. The foliations $\left(\mathrm{S}_{1}\right.$ or $\left.\mathrm{S}_{2}\right)$ dipping $\mathrm{SW}$ in quartz schist $\left(\mathrm{Pt}_{2}\right)$ may represent earlier overshear deformation in the NHMB. Asymmetric augen in amphibole gneiss in the Huoshan area indicates shearing towards the NE. Using the optical microscope, garnet in quartz schist has a "snowball" texture and also confirms that NE-directed shearing (Figure 2(a)).

According to a systematical strain-measurement analysis of the snowball textures in garnet and deformed quartz grains, the shear strain $(\gamma)$ in the central part of the north detachment zone is up to 2.6 and gradually decreases outward. Measurements of a rock finite strain in the detachment zone indicated that the shear displacement is at least $56 \mathrm{~km}$.
3.2. The South Extensional Tectonic System. The south extensional tectonic system is composed mainly of one deep ductile shear zone and ltwo brittle-ductile shear zones.

3.2.1. One Deep Ductile Shear Zone (Shuihou-Wuhe). The Shuihou-Wuhe ductile shear zone (SH-WH SZ) consists of feldspar mylonite and formed under lower crustal conditions; the shear zone was named the "first southern detachment zone" by Zhong et al. [20]. The shear zone dips towards the S, SSW, and SSE at an angle of $40-60^{\circ}$. The S-C shear fabrics, sheath folds, and shear folds in the shear zone consistently dip towards the south (Figures 3(a) and 3(b)). Much of these extensional shear deformations superpose on earlier thrust-shearing deformation and strikeslip deformation. The shear strain $(\gamma)$ in the zone is up to 5 , such as observations in the north of Yingshan (Figure 3(a)). 


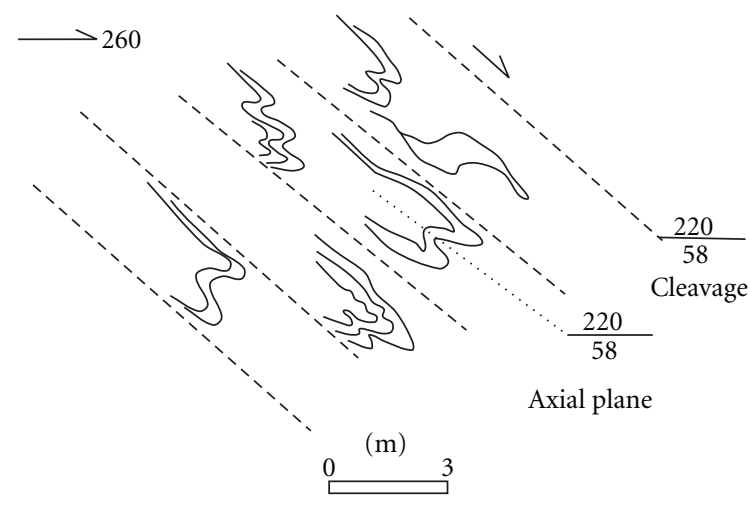

(a) Zhangzui

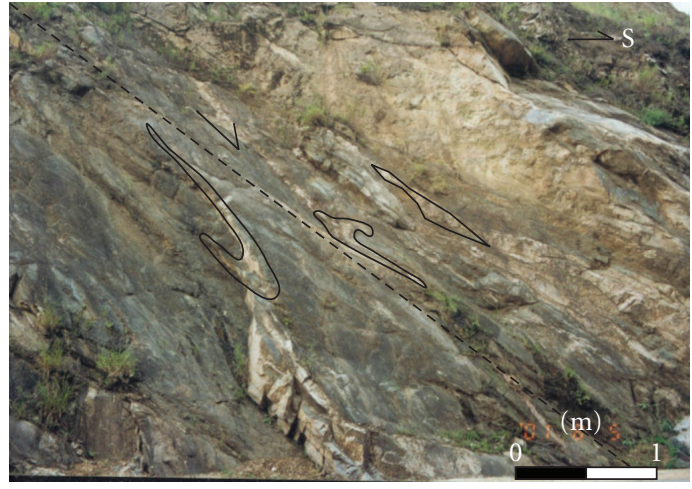

(b) Yazhangshu

FIGURE 3: Quartz bands in gneiss in the Shuihou-Wuhe shear zone, the shear zone dips SSW; (a) and (b) are, respectively, from places the Zhangzui village and the Yazhangshu primary school of the Yingshan County.

Based on strain-measurement analysis, the strain ellipsoid of the shear zone displays the Flinn parameter $(K)$ range of 0.01-0.1, corresponding with pancake-shape flattening and reflecting intense compression and pure shear deformation.

According to the fabric analysis of deformed quartz, the small-circle belt at the east segment of the SH-WH SZ reflects high-temperature deformations conditions $\left(>700^{\circ} \mathrm{C}\right)$ and relatively slow strain-rate velocity $\left(10^{-7} \mathrm{~s}^{-1}\right)$. The middle segment was asymmetric with point belonging to a rhomb slide system, which reflects middle-high-temperature deformational conditions $\left(650-700^{\circ} \mathrm{C}\right)$. The quartz fabric analysis also shows that the principal stress direction was oriented NE-SW, which is consistent with the principal stress direction determined from the preferred orientation of amphibole long axes. The paleodifferential stress was calculated at about $92 \mathrm{Mpa}$ based on quartz dislocation density.

\subsubsection{Two Brittle-Ductile Shear Zones (Taihu-Mamiao, Susong-Qingshuihe)}

(a) The Taihu-Mamiao Shear Zone. The Taihu-Mamiao shear zone (TH-MM SZ) lies to the south of the SH-WH SZ and is bounded by the southern Dabie and Susong metamorphic zones in the north and south, respectively (Figure 1). The TH-MM SZ dips mainly towards the S or SSE; the dip angle changes from steep to gentle with increasing depth. A series of recumbent folds, S-C shear fabrics, asymmetric augen, extensional lineations in some profiles indicate that extension was to the SSE (Figures 4(a) and 4(b)). Based on strain-measurement analysis, the Flinn parameter for the shear zone is about 1 , indicating a planar strain.

(b) The Susong-Qingshuihe Shear Zone. The Susong-Qingshuihe shear zone (SS-QSH SZ) lies to the south of the THMM SZ and to the north of the Xiangfan-Guangji fault (XFGJ F.). The SS-QSH SZ marks the interface between highpressure eclogite and blueschist units (Figure 1). The stretch lineation of monzogranitic mylonite in Qingshuihe plunges towards the SSW. According to strain-measurement analysis, the Flinn parameter of the shear zone is more than 7, which suggests cigar-shaped, extensional deformation. The shear displacement along the detachment zone is more than $12 \mathrm{~km}$ based on strain measurement analysis. Deformed quartz displays asymmetic point coarctation, belonging to a rhomb slide system, and suggesting middle-to-high temperatures during deformation. Based on the dislocation density of quartz, we calculated the paleodifferential stress $70-84 \mathrm{Mpa}$, which is smaller than that of the SH-WH SZ.

Based on the structural analysis above, the three shear zones in the south extensional tectonic system probably represent deeper, middle, and upper detachment systems, ranging from north to south, respectively. Deformation temperatures and differential stresses decrease from the northern Dabie complex to the south. Remarkably, strain changes from north to south; from flattened (i.e., $K \ll 1$ ) in the northern the SH-WH SZ, to planar (i.e., $K \approx 1$ ), and then to extensional strain (i.e., $K \gg 1$ ) in the southern SSQSH SZ. This transition of strain reflects the influence of magmatic intrusion during the extensional detachment.

\section{Chronological Constraints on the Extensional Detachment}

${ }^{40} \mathrm{Ar} /{ }^{39} \mathrm{Ar}$ dating of biotite and hornblende from the four extensional detachment zones in Dabie area are shown in Table 1 . The data can be divided into two groups, ca. $124 \mathrm{Ma}$ and ca. $190 \mathrm{Ma}$, respectively. The north extensional tectonic system and the SS-QSH SZ were active at ca. $124 \mathrm{Ma}$, representing the time of extensional detachment to this period. In contrast, the SH-WH and TH-MM SZs, on the north and south sides of ultrahigh-pressure metamorphic zone, respectively, have ages of ca. $190 \mathrm{Ma}$, representing the time of exhumation of ultrahigh-pressure metamorphic rocks.

\section{Discussion}

The north extensional detachment zone hosts a shear zone that cuts the Late Proterozoic Xinyang Group $\left(\mathrm{Pt}_{2} \mathrm{n}\right)$ micaquartz schist. The shear zone contains allochthonous blocks 


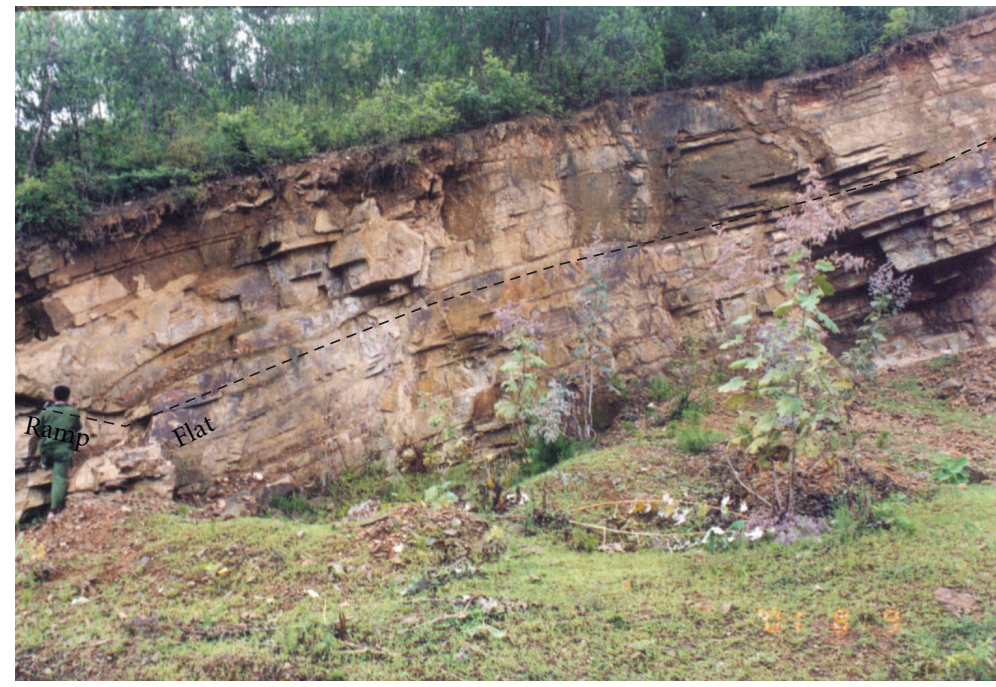

(a)

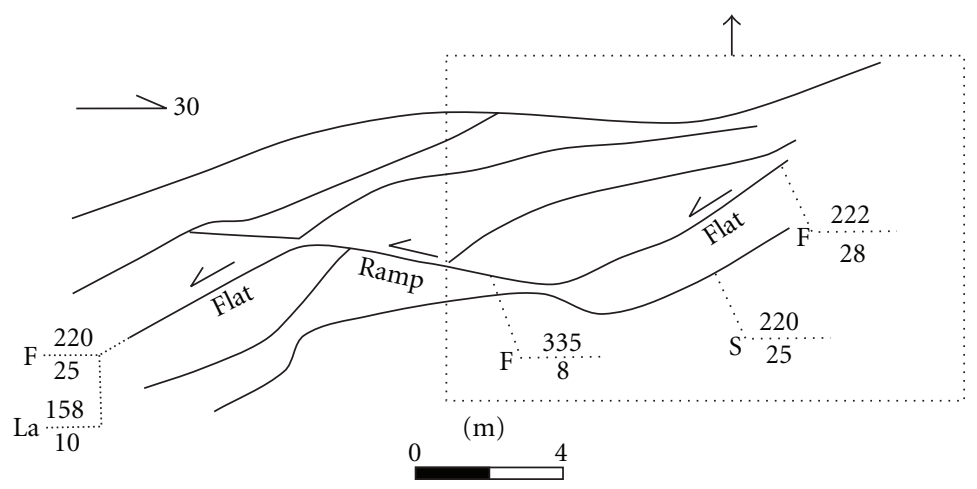

(b)

FIGURE 4: Extensional flat-ramp structure in the Taihu-Mamiao shear zone, indicating S-extension (near Luoxi village along the road between Liuyang and Hualiangting in the Taihu County). The occurrences of gneiss cleavage, flat and ramp, and extensional lineation are marked.

TABLE 1: Summary of mineral ${ }^{40} \mathrm{Ar}^{39} \mathrm{Ar}$ data in the main shear zone of eastern Dabie Mountains.

\begin{tabular}{lccc}
\hline Shear zone & Sample locations & Mineral & Weighted mean plateau age (Ma) \\
\hline \multirow{2}{*}{ XT-MZT SZ } & Qingshan town & Biotite & $124.17 \pm 0.25$ \\
& Zhangchong village & Biotite & $126.91 \pm 0.30$ \\
\hline SH-WH SZ & Shuihou village & Biotite & $190.59 \pm 0.42$ \\
\hline \multirow{2}{*}{ TH-MM SZ } & Luoxi village & Hornblende & $197.41 \pm 0.46$ \\
& Luoxi village & Biotite & $189.42 \pm 0.29$ \\
\hline \multirow{2}{*}{ SS-QSH SZ } & Qingshuihe village & Biotite & $124.87 \pm 0.21$ \\
& Chenhan village & White mica & $194.01 \pm 0.36$ \\
\hline
\end{tabular}

of Late Jurassic volcaniclastic rocks and tuff that are up to several meters in size (Figure 2).

Large-scale, harmonic, recumbent folds also occur in the Late Jurassic volcaniclastic rocks and the Late Proterozoic mica schist. In the south extensional detachment system, the Hong'an Group $(\mathrm{Pt})$ and Yanshanian granite $\left(\mathrm{J}_{3}-\mathrm{K}_{1}\right)$ experienced extensional shear deformation at the same time. These features suggest that the extensional detachment of both the south and north detachment systems took place after the Late Jurassic.

The age group $\sim 200 \mathrm{Ma}$ is coincide with the $\mathrm{U}-\mathrm{Pb}$ ages, Sm-Nd ages, and Rb-Sr ages of UHP rocks [22-26], which reflect protracted cooling or partial resetting by Jurassic or Cretaceous magmatism.

In addition, massive granitic intrusions and numerous ultrabasic plutons were emplaced in the NDMCB during 
TABLE 2: The comparison of deformation ages from southern Dabie belt of China.

\begin{tabular}{|c|c|c|c|}
\hline Age groups & \multicolumn{2}{|c|}{ Data of XT-MZT SZ [21] } & Our data from other shear zones \\
\hline \multirow{2}{*}{$\sim 200 \mathrm{Ma}$} & & & $229.8 \pm 70.97$ \\
\hline & & & $219.52 \pm 1.57$ \\
\hline \multirow{5}{*}{$150 \sim 190 \mathrm{Ma}$} & \multirow{5}{*}{\multicolumn{2}{|c|}{$156.7 \pm 1.5$}} & $197.41 \pm 0.46$ \\
\hline & & & $194.01 \pm 0.36$ \\
\hline & & & $190.59 \pm 0.42$ \\
\hline & & & $189.42 \pm 0.29$ \\
\hline & & & $156.5 \pm 7.15$ \\
\hline \multirow{7}{*}{$145 \sim 110 \mathrm{Ma}$} & $136.5 \pm 1.3$ & $132.0 \pm 0.8$ & \\
\hline & $129.8 \pm 0.6$ & $141.9 \pm 1.2$ & \\
\hline & $129.2 \pm 1.0$ & $127.1 \pm 0.7$ & $127.96 \pm 0.30$ \\
\hline & $133.1 \pm 0.9$ & $128.3 \pm 0.9$ & $124.87 \pm 0.21$ \\
\hline & $134.1 \pm 0.9$ & $127.0 \pm 0.8$ & $124.56 \pm 2.4$ \\
\hline & $136.8 \pm 1.1$ & $122.5 \pm 0.6$ & \\
\hline & $130.7 \pm 1.0$ & $120.7 \pm 0.7$ & \\
\hline
\end{tabular}

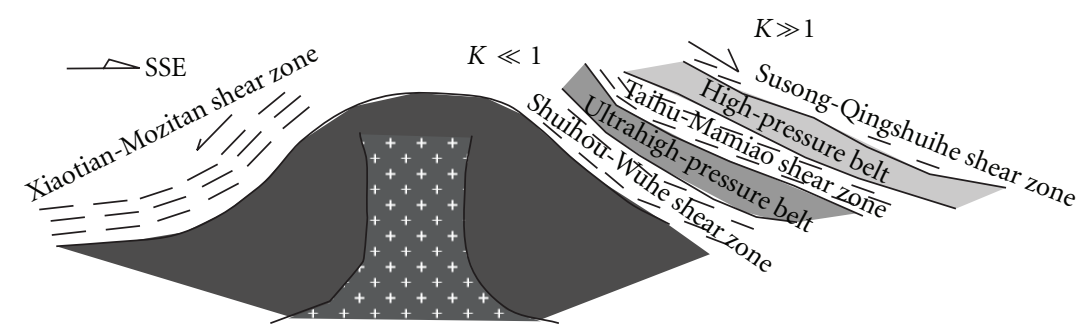

FIGURE 5: Extensional detachment model for the late Mesozoic in the Dabie Mountains.

the extensional phase at about $120 \mathrm{Ma}$. The Ar-Ar and $\mathrm{Rb}-\mathrm{Sr}$ isotopic analyses of rocks in the Dabie group also record this time at about $110-145 \mathrm{Ma}$ (Table 2). All these lines of evidence suggest that they were closely related to extensional detachment. The Cretaceous lacustrine, fluvial, and piedmont facies (several kilometers thick in the Hefei basin) also reflect a regional extensional setting and intense mountain-basin movement. Therefore, voluminous magmatic emplacement and lithosphere delamination during the early Cretaceous induced the rapid uprising of the North Dabie central area, with extensional detachment on both sides. The intense denudation resulted in the thick sediment deposits in the Hefei basin. The high- and ultrahighpressure eclogites were probably emplaced during this event (Figure 5). Large-scale extension in the Dabie Mountains during the late Mesozoic is representative of the tectonic regime inversion that affects the eastern North China Block.

Lastly, the deposition of platinum group elements (PGEs) in ultramafic and/or mafic rocks with two ages, ca. $120 \mathrm{Ma}$ and ca. $230 \mathrm{Ma}$, in the North Dabie complex core suggests that their source region was the upper mantle. The PGE data indicate that the late Mesozoic upper mantle (ca. $120 \mathrm{Ma}$ ) enriched in PGE, whereas depleted PGE before $120 \mathrm{Ma}$. The late Mesozoic upper mantle with PGE enrichment in the Dabie region is contaminated with about $8 \%$ Earth core materials, as the PGE contents in the Earth's core are much higher than in the upper mantle $[27,28]$. If this is correct, then the PGE mantle enrichment must be related to the late Mesozoic extensional detachment in the Dabie area.

\section{Conclusions}

(1) The main shear zones in the Dabie area are characterized by extensional detachment during late Mesozoic era. The XT-MZT SZ is detached to the NNE, the SH-WH SZ, and the TH-MM SZ are displaced to the SSE, while the SSQSH SZ is displaced to the SW.

(2) The shear length of the XT-MZT SZ is more than $56 \mathrm{~km}$ and that of the SS-QSH SZ is more than $12 \mathrm{~km}$. The Flinn parameter of the Shuihou-Wuhe shear zone is much smaller than 1 (i.e., $0.01-0.1$ ), which suggests that the shear zone was flattened when it formed. The Flinn parameter of the Taihu-Mamiao shear zone is about 1 (i.e., 1.1), whereas the Susong-Qingshuihe shear zone is much more than 1 (i.e., 7.6), which suggests that they were formed during extension. From north to south in the south extensional tectonic system, these Flinn parameter values display the transition from pure shear to simple shear, possibly reflecting the active intrusion of magma during the extensional detachment.

(3) Two deformation ages, $\sim 190 \mathrm{Ma}$ and $\sim 124 \mathrm{Ma}$ based on mineral ${ }^{40} \mathrm{Ar}-{ }^{39} \mathrm{Ar}$ data, are concluded from the main shear zones in the Dabie area. The early age ( 190 Ma) could be related to the UHP cooling and reversion during orogenesis, whereas the later one $(\sim 124 \mathrm{Ma})$ could represent 
the extensional detachment age after the formation of the orogeny.

(4) The strain analysis, chronology, and the mantle enrichment in platinum group elements suggests that magmatic intrusion in the north Dabie complex core is the main cause for extensional detachment structures during the late Mesozoic.

\section{Acknowledgments}

The authors thank Professors Jiliang Li, Wenjiao Xiao, Mingguo Zhai, and Zhihong Wang from the Institute of Geology and Geophysics, Chinese Academy of Sciences, and Tianshan Gao from the University of Science and Technology of China for the excellent field and inner laboratory discussions; they also thank Dr. Paul Duuring from The University of British Columbia, Canada for much help. This work is supported by the National Natural Science Foundation of China (Grant no. 41030422), the Major Project of Chinese Academy of Sciences (Grants KZCX1-07), and the Key project of the National Natural Science Foundation of China (Grant no. 40234050).

\section{References}

[1] S. Li, T. M. Kusky, X. Liu et al., "Two-stage collisionrelated extrusion of the western Dabie HP-UHP metamorphic terranes, central China: evidence from quartz c-axis fabrics and structures," Gondwana Research, vol. 16, no. 2, pp. 294309, 2009.

[2] S. Z. Li, X. Liu, Y. H. Suo et al., "Triassic folding and thrusting in the Eastern Block of the North China Craton and the DabieSulu orogen and its geodynamics," Acta Petrologica Sinica, vol. 25, pp. 2031-2049, 2009.

[3] S. Z. Li, T. M. Kusky, G. Zhao et al., "Mesozoic tectonics in the Eastern Block of the North China Craton: implications for subduction of the Pacific plate beneath the Eurasian plate," Geological Society Special Publication, no. 280, pp. 171-188, 2007.

[4] S. Suo, Z. Zhong, and Z. You, "Extensional deformation of post ultrahigh-pressure metamorphism and exhumation process of ultrahigh-pressure metamorphic rocks in the Dabie massif, China," Science in China, Series D, vol. 43, no. 3, pp. 225-236, 2000.

[5] E. Eide, "A model for the tectonic history of HP and UHPM regions in east central China," in Ultrahigh-Pressure Metamorphism, R. G. Coleman and X. M. Wang, Eds., pp. 391426, Cambridge Press, 1995.

[6] X. M. Wang, R. Y. Zhang, and J. G. Liou, "UHPM terrane in east central China," in Ultrahigh Pressure Metamorphism, R. G. Coleman and X. M. Wang, Eds., pp. 356-390, Cambridge University Press, Cambridge, UK, 1995.

[7] B. L. Cong, Ultrahigh-Pressure Metamorphic Rocks in the Dabieshan-Sulu Region of China, Kluwer Academic Publishers, Science Press Beijing, 1996.

[8] B. R. Hacker, X. Wang, E. A. Eide, and L. Ratschbacher, "The qinling-dabie ultrahigh-pressure collisional orogen," in The Tectonic Evolution of Asia, A. Yin and T. M. Harrison, Eds., pp. 345-370, Cambridge University Press, Cambridge, UK, 1996.

[9] J. G. Liou, R. Y. Zhang, X. M. Wang, E. A. Eide, W. G. Ernst, and S. Maruyama, "Metamorphism and tectonics of highpressure and ultrahigh-pressure belts in the Dabie-Su-Lu region, China," in The Tectonic Evolution of Asia, A. Yin and T. M. Harrison, Eds., pp. 300-344, Cambridge University Press, Cambridge, UK, 1996.

[10] B. M. Jahn, F. Wu, C. H. Lo, and C. H. Tsai, "Crust-mantle interaction induced by deep subduction of the continental crust: geochemical and $\mathrm{Sr}-\mathrm{Nd}$ isotopic evidence from postcollisional mafic-ultramafic intrusions of the northern Dabie complex, central China," Chemical Geology, vol. 157, no. 1-2, pp. 119-146, 1999.

[11] S. Li, T. M. Kusky, G. Zhao et al., "Two-stage Triassic exhumation of HP-UHP terranes in the western Dabie orogen of China: constraints from structural geology," Tectonophysics, vol. 490, no. 3-4, pp. 267-293, 2010.

[12] S. Z. Li, G. C. Zhao, G. W. Zhang et al., "Not all folds and thrusts in the Yangtze foreland thrust belt are related to the Dabie Orogen: insights from Mesozoic deformation south of the Yangtze River," Geological Journal, vol. 45, no. 5-6, pp. 650$663,2010$.

[13] S. Li, T. M. Kusky, G. Zhao et al., "Thermochronological constraints on two-stage extrusion of HP/UHP terranes in the Dabie-Sulu orogen, east-central China," Tectonophysics, vol. 504, no. 1-4, pp. 25-42, 2011.

[14] S. Suo, L. Sang, Y. Han et al., The Petrology and Tectonics in Dabie Precambrian Metamorphic Terranes, Central China, China University of Geosciences Press, Wuhan, China, 1993.

[15] H. L. Song, "Early extensional tectonics in Qinglin-Dabie orogen," in Extensional Tectonics Research, X. L. Qian, Ed., pp. 12-21, Geology Press, Beijing, China, 1994.

[16] Q. Zhang, W. P. Ma, J. W. Jin et al., "Geochemistry and tectonic significance of post-tectonic gabbro from Wangmuguan of Xinxian county, Henan province," Chinese Journal of Geochemistry, vol. 24, 4, pp. 341-350, 1995.

[17] W. Jin, H. Song, and W. Ma, "Extensional tectonics in tongbaiwest Dabie mountain,” Scientia Geologica Sinica, vol. 32, no. 2, pp. 156-164, 1997.

[18] G. C. Wang and W. R. Yang, "Uplift evolution during Mesozoic-Cenozoic of the Dabie orogenic belt: evidence from the tectono-chronology," Earth Science-Journal of China University of Geosciences, vol. 23, no. 5, pp. 461-467, 1998.

[19] J. Li, The Dabie Shan main shear zone of Late Mesozoic and extension structure [M.S. thesis], Institute of Geology and Geophysics, Chinese Academy of Sciences, 2003.

[20] Z. Q. Zhong, S. Suo, and Z. D. You, "Extensional tectonic framework of post high and ultrahigh pressure metamorphism in Dabieshan, China," Earth Science-Journal of China University of Geosciences, vol. 23, no. 3, pp. 225-229, 1998.

[21] Y. S. Wang, B. W. Xiang, G. Zhu et al., " ${ }^{40} \mathrm{Ar}-{ }^{39}$ Ar geochronology records for post-orogenic extension of the XiaotianMozitan fault," Geochimica, vol. 38, pp. 458-471, 2009.

[22] L. E. Webb, L. Ratschbacher, B. R. Hacker et al., "Kinematics of exhumation of high-and ultrahigh-pressure rocks in the Hong'an and Tongbai Shan of the Qinling-Dabie collisional orogen, eastern China," GSA Memoirs, vol. 194, pp. 231-245, 2001.

[23] J. C. Grimmer, L. Ratschbacher, M. McWilliams et al., "When did the ultrahigh-pressure rocks reach the surface? A $207 \mathrm{~Pb} / 206 \mathrm{~Pb}$ zircon, ${ }^{40} \mathrm{Ar}-{ }^{39} \mathrm{Ar}$ white mica, Si-in-white mica, single-grain provenance study of Dabie Shan synorogenic foreland sediments," Chemical Geology, vol. 197, no. 1-4, pp. 87-110, 2003. 
[24] B. R. Hacker, S. R. Wallis, L. Ratschbacher, M. Grove, and G. Gehrels, "High-temperature geochronology constraints on the tectonic history and architecture of the ultrahigh-pressure Dabie-Sulu orogen," Tectonics, vol. 25, no. 5, Article ID TC5006, 2006.

[25] B. R. Hacker, S. R. Wallis, M. O. Mcwilliams, and P. B. Gans, " ${ }^{40} \mathrm{Ar}-{ }^{39} \mathrm{Ar}$ constraints on the tectonic history and architecture of the ultrahigh-pressure Sulu orogen," Journal of Metamorphic Geology, vol. 27, no. 9, pp. 827-844, 2009.

[26] B. R. Hacker, L. Ratschbacher, and J. G. Liou, "Subduction, collision and exhumation in the ultrahigh-pressure QinlingDabie orogen," Geological Society Special Publication, no. 226, pp. 157-175, 2004.

[27] Q. Liu, Study on the distribution of Platinum group elements in Dabie (ultra-) mafic rocks and Fuxin volcanic rocks [Ph.D. thesis], Graduate University of the Chinese Academy of Sciences, 2005.

[28] Q. Liu, Q. L. Hou, X. H. Zhou, and L. W. Xie, "The distribution of platinum-group elements in gabbros from Zhujiapu, Dabie orogen," Acta Petrologica Sinica, vol. 21, no. 1, pp. 227-239, 2005. 

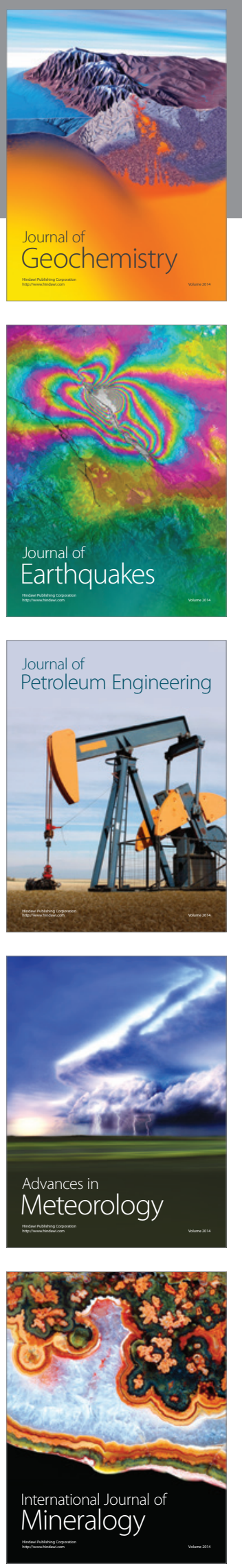
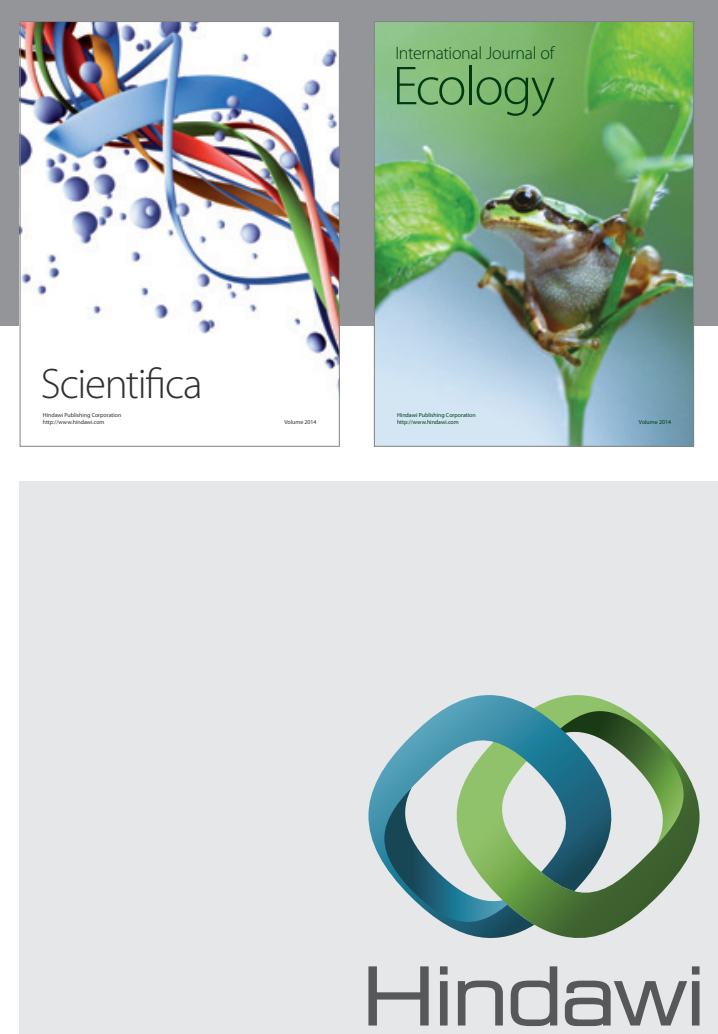

Submit your manuscripts at http://www.hindawi.com
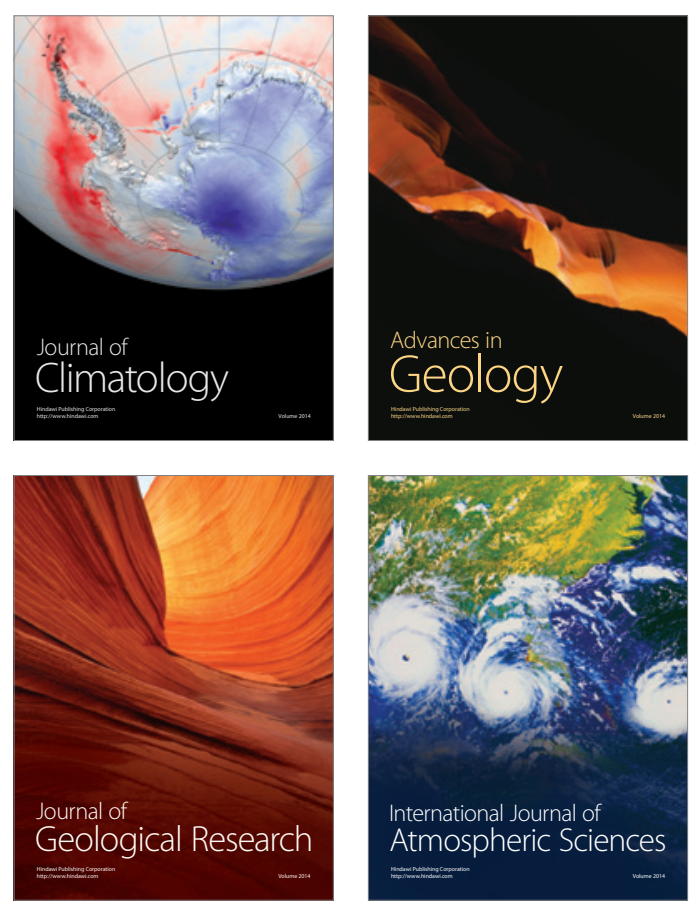
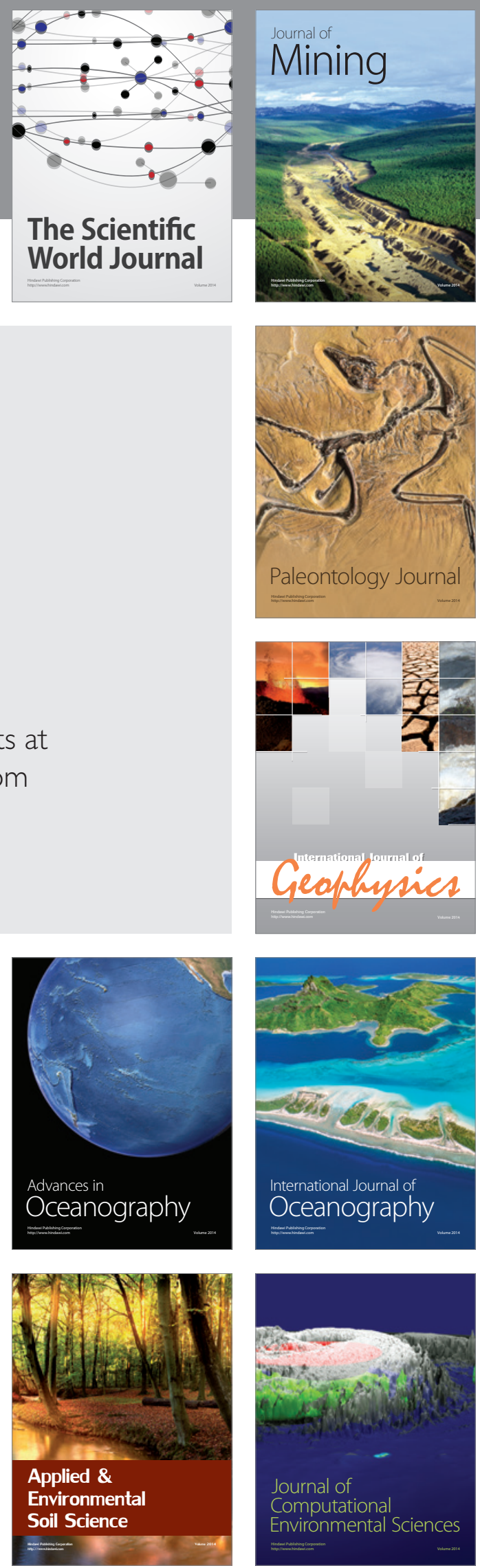